\title{
The Ambiguity of Kant's ConcePt OF THE Visible ChURCH
}

\author{
- Gordon E. Michalson, Jr. -
}

\begin{abstract}
This paper explores the implications of Manfred Kuehn's observation that Kant's claim in Religion within the Boundaries of Mere Reason that the ethical community must be a community under God seems "a bit strained." After clarifying Kant's train of thought that results in his conception of the ethical community in the form of the "visible church," the paper argues that the seemingly strong religious dimension may be misleading. If we understand the ethical community to be the development of the kingdom of ends in the Groundwork, it becomes apparent that Kant's notion of God's "sovereignty" over the ethical community is a shared sovereignty lodged in rationality and not in God's own will. The "strain" that Kuehn senses thus suggests the potentially gratuitous nature of Kant's references to God's sovereignty over the ethical community. Despite the initial appearances, Kant's account of the ethical community in the form of the visible church is, over the long term, closer to a secularizing move than to a robustly religious one.
\end{abstract}

Keywords: Kant, religion, ethical community, God, kingdom of ends, secularization.

Published online: 25 August 2020

At one point in his distinguished biography of Immanuel Kant, Manfred Kuehn summarizes Kant's account of the ideal ethical community, a community that Kant himself depicts as a veritable "kingdom of God on earth." Naturally, if such a community is to be truly "ethical" by Kantian standards, it must be united under the "laws of virtue alone" rather than subject to the heteronomous features of traditional political arrangements.

In surveying this section of Kant's late work, Religion within the Boundaries of Mere Reason, Kuehn correctly notes that "Kant goes on to argue that such a community needs to be understood as a church," or a people of God. For Kant, not only does the church provide a safe zone for autonomy, but it also offers the hope that, over time, "there will eventually arise the "pure faith' of moral religion." ${ }^{1}$ Kuehn goes on to state: "These views of Kant seem a bit strained, especially his argument that the ethical community must be a community under God." Kuehn offers little follow-up to this observation, but his specific sensitivity to the involvement of God in Kant's view of the ethical community

Gordon E. Michalson, Jr.

New College of Florida

5800 Bay Shore Road

Sarasota, FL 34235

USA

email: michalson@ncf.edu

${ }^{1}$ Kuehn (2001): 369-370, emphasis added. 
is both helpful and suggestive. Kuehn's way of framing the matter clearly signals that there is something conceptually awkward about sustaining references to God while simultaneously depicting moral progress in terms of an autonomous rationality. After all, the imperative to create an ethical community is driven for Kant by certain needs of reason rather than by divine commands of a more traditional sort. If this is the case, then a possible side effect of Kant's effort to explain God's relation to moral progress may be a gradual diminishing of the actual role for divine agency to play, which would of course result in the long-term reduction rather than enhancement of the role of religion. Rather paradoxically, there emerges a potential asymmetry between the elevation of religious themes conveyed by Kant's appeal to the church and a latent but growing irrelevance of references to God in the account of establishing the ethical community. The "strain" that Kuehn detects may thus be due to Kant's effort to maintain references to divine agency in an account that has less and less need for them.

This point can be difficult to see at first, since Kant's turn to the church rather than to a political context for describing the ethical community initially appears to be a compliment to religion. ${ }^{2}$ Upon examination, however, Kant's gesture could turn out to be a back-handed compliment, suggesting that his appeal to the visible church in Religion may be fundamentally ambiguous. Indeed, a certain ambiguity is already present in Kant's telling references to ecclesiastical faith - for which the visible church is the institutional expression - as the "vehicle" for pure moral faith. ${ }^{3}$ Viewed in terms of the metaphor of a "vehicle," the church in its role as an ethical institution would appear to be the conveyer of the final goal and not the goal itself. In short, it may turn out that, when Kant opened Religion within the Boundaries of Mere Reason by stating that "on its own behalf morality in no way needs religion," he really meant it (RGV 6:3).

My main interest in what follows, then, is to identify moments of ambiguity in Kant's view of the visible church in order to assess the status of religion and religious issues in relation to what has been called Kant's concern for "noncoercive ethical institutions." 4 To provide some background for this account, I will initially trace in general terms the largely familiar line of thinking that leads Kant to his consideration of the visible church in the first place.

\section{Ethical Life and the Community}

As Kuehn's biography reminds us, Kant develops his account of the visible church as the institutional locus of an ethical community in Part Three. A central aim of Part Three is to develop a "social" solution to the problem of radical evil that Kant depicts in Parts

\footnotetext{
${ }^{2}$ In a recent issue of Diametros, a fresh exploration of the more strictly religious interpretive option has been offered by Stephen Palmquist (2017), who proposes that Kant's account leads toward what Palmquist calls "a non-coercive theocracy."

${ }^{3}$ E.g., Kant (1793/1996), RGV 6:115. Hereafter references to Kant's Religion will be in parentheses in the text, indicated as RGV, followed by volume and page number in the German Academy edition. The same format regarding pagination in the relevant German Academy edition will be followed in footnotes to other works by Kant. All English translations are taken from the relevant volume in the Cambridge Edition of the Works of Immanuel Kant.

${ }^{4}$ DiCenso (2019): 31.
} 
One and Two, a problem resulting from a human "propensity to evil" that corrupts the moral disposition, the very source of our maxim-making (RGV 6:35-7). ${ }^{5}$ There is irony in this shift to the social context to solve this problem. Kant's own earlier account of our original "predisposition to humanity" had disclosed the ways in which the social setting itself corrupts the individual's originally "good" natural tendency "to gain worth in the opinion of others" by bringing about the fall into "envy, ingratitude, and joy in others' misfortunes" (RGV 6:27). Kant in fact repeats this very point at the beginning of Part Three: "Envy, addiction to power, avarice, and the malignant inclinations associated with these assail his nature, which on its own is undemanding, as soon as he is among human beings" (RGV 6:93-4; emphasis Kant's). He goes on rather bleakly to depict how our original "juridical state of nature" involving a "state of war of every human being against every other" finds an unfortunate parallel in our "ethical state of nature" in which "the good principle" residing in each human being "is incessantly attacked by the evil which is found in him and in every other as well" (RGV 6:96-7). Allen Wood's succinct characterization is apt: for Kant, "it is always in a social context that we display the propensity to evil." 6

The irony here, of course, is that, in his accompanying efforts to conceptualize an "ethical community" that might combat the negative tendencies of our common life, Kant re-visits the idea of community, though now with a view to its potential to awaken rather than undermine our moral capacities. ${ }^{7}$ Given the starkly negative terms in which Kant has already depicted the moral influences of life together in community, the task facing any form of community endeavoring to deliver moral progress will be prodigious indeed. Just here is where Kant signals the advantages of a religious over against a political institutional setting for promoting authentic moral ends, due mainly to the voluntary features of the former as opposed to the heteronomous aspects of the latter. Drawing out the implications of his parallel accounts of a "juridical state of nature" and an "ethical state of nature," Kant offers the key distinction.

A juridico-civil (political) state is the relation of human beings to each other inasmuch as they stand jointly under public juridical laws (which are all coercive laws). An ethico-civil state is one in which they are united under laws without being coerced, i.e., under laws of virtue alone (RGV 6:95; emphasis Kant's).

Here Kant is simply pursuing his own familiar point that ethical development is incompatible in principle with heteronomy. Providing a note of emphasis to the connection between autonomy and authentic virtue, he famously adds, "woe to the legislator who

\footnotetext{
${ }^{5}$ See the helpful and complementary accounts of the shift toward community in light of radical evil in three recent commentaries on Religion: DiCenso (2012): 131-150; Pasternack (2014): 174-181; and Miller (2015): 84-92. See also Wood (2011): 131-136.

${ }^{6}$ Wood (2011): 132. See also Wood (1999): 286-289 and the response to Wood's position by Grenberg (2010).

7 Numerous commentators have noted Kant's previous turn to community in his earlier (1784) Idea for a Universal History with a Cosmopolitan Aim as a solution to what he refers to as the "crooked wood of humanity." In that context Kant opens up the multiple facets of what he calls our "unsocial sociability," a process now continued in Religion. See Wood (2011): 131-132; Guyer (2009): 129-149; DiCenso (2019): 30-31; Pasternack (2014): 177-178.
} 
would want to bring about through coercion a polity directed to ethical ends!" (RGV 6:96). Within a juridico-civil state, it may be possible to enforce legality, but not morality. He is thus exploring what one commentator has recently identified as Kant's ethical interest in "nonstate institutions that inform modes of thinking and shape the communicative spaces in which the free choice (Willkür) of rational beings operates." ${ }^{8}$

It is in the course of his effort to depict an ideal ethical community based upon "the laws of virtue alone" and not on "coercive laws" that Kant's train of thought ultimately leads to his account of the visible church. His initial step in this direction discloses the way Kant's appeal to universality as intrinsic to rationality itself will assume driving argumentative force in conceiving the ethical community. Since "the duties of virtue concern the entire human race," he tells us, "the concept of an ethical community always refers to the ideal of a totality of human beings, and in this it distinguishes itself from a concept of a political community" (RGV 6:96; emphasis added). In other words, the political community is disqualified from serving as the locus of the ideal ethical community not only because of its heteronomous dimension but also because of its inability to achieve the universal reach of ethical demands. To some degree, political communities will always be parochial, while the authentic ethical community ought to embody a cosmopolitanism that, in its most authentic form, will be universal in its scope.

\section{"A Duty Sui Generis" and the Visible Church}

With these differences between religious and political settings thus clarified in his own terms, Kant proceeds to expand his appeal to universality through the formulation of what he announces as a "duty sui generis" (eine Pflicht von ihrer eignen Art). This duty sui generis is a duty "not of human beings toward human beings but of the human race toward itself" (RGV 6:97). In explaining this special duty, Kant claims that rational beings are "objectively," through the very idea of reason, "destined to a common end, namely, the promotion of the highest good as a good common to all." The turn to community in decisive form emerges in his amplification of this point. Kant explains that the "highest moral good will not be brought about solely through the striving of one individual for his own moral perfection." Rather, the highest moral good requires "a union of such persons into a whole toward that very end ... toward a system of well-disposed human beings in which, and through the unity of which alone, the highest moral good can come to pass" (RGV 6:97-8; emphasis added).

This duty is sui generis, then, because of the distinctive way in which the moral agent's individual obligation becomes inseparable from its obligation to the entire community of rational beings, without whom the individual's moral strivings are both insufficient and incomplete. In this one case, consideration of the individual moral agent cannot be separated out from the "human race" to which it belongs. Implicit in this position - and characteristic of Kant's ethical theory more generally - is the important insight that self-respect is inseparable from respect for others. As one commentator has framed the matter, Kant effectively conceives of an ethical society as "a community composed

\footnotetext{
${ }^{8}$ DiCenso (2019): 40.
} 
of members affirming each other's worth and supporting each other's moral striving" in ways that are mutual and reciprocal. ${ }^{9}$ Kant's concentrated attention in Religion toward a duty that is sui generis demonstrates how the moral imperative to promote the ethical community is embedded objectively in the very idea of exercising one's own autonomy. Kant's depiction of this "duty sui generis" thus stimulates in rational terms the shift from an individual to a community perspective on the ideal ethical life. At the same time, Kant acknowledges that the sum total of moral strivings of a community of individually fallible moral agents will not yield the highest moral good that is the aim of this special duty. Consequently, "this duty will need the presupposition of another idea, namely, of a higher moral being through whose universal organization of forces the single individuals, insufficient on their own, are united for a common effect" (RGV 6:98). Similarly, if this community is to have associated with it an agent capable of judging the moral status of its members, there "must also be one who knows the heart" and can reach "the most intimate parts of the dispositions" of those members. "But this is the concept of God," Kant declares in drawing the obvious conclusion to his own train of thought (RGV 6:99). We thereby see that God's role is to offset the insufficiency of the collective moral acts of rational yet finite agents while also judging by means of the noumenal divine "eye" the moral status of the community's members "and, as must be in every community, give to each according to the worth of his actions" (RGV 6:99).

Worth noting here is that Kant has basically repeated the same reasoning process associated with the postulation of God's existence in the Critique of Practical Reason. In that earlier context, Kant's depiction of the "highest good," understood as the proportioning of virtue and happiness, required a being "who knows the heart" of the moral agent and who also possesses the capacity to "give to each according to the worth of his actions" (KpV 5:92-93). This of course is the very same set of issues at stake now in Religion. What has changed is that, in that earlier context, the issue at stake is the moral agent's fate as an individual, whereas the issue at stake now in Religion is the fate of the community of moral agents. Notably, this change in perspective is simultaneously a shift from what we might call the "vertical" relationship the individual has to an ultimate immortality of the soul in the second Critique to a "horizontal" relationship that the entire community of moral agents has to its future ethical goal. Kant may well revisit in Religion a reasoning process similar to that originally offered in the second Critique, but he also introduces significant changes that point toward what has been characterized as "heaven coming to earth." 10 The exact extent to which the realization of the highest moral good in community terms actually occurs in history is a matter of largely unresolved debate.

The train of thought put in motion by Kant's notion of a duty sui generis ultimately leads to his account of the visible church. Due to the human limitations he has outlined - both ethical and epistemological - Kant re-states the imperative emerging from the duty sui generis in a manner that discloses the need for divine partnership. An

\footnotetext{
9 Sullivan (1994): 88. While not dealing directly with Religion, Robert Louden's Anthropology from a Kantian Point of View: Toward a Cosmopolitan Conception of Humanity implicitly offers constructive ways to connect Kant's notion of the universality driven elements of a "duty sui generis" to the mix of pragmatic elements typical of life in community. Louden (2011): 77-90.

${ }^{10}$ Michalson (1999): chapter 5.
} 
"ethical community is conceivable only as a people under divine commands" (RGV 6:99), he affirms, subsequently adding that we must therefore conclude that such a community "under divine legislation is a church" (RGV 6:101; emphasis Kant's). He initially depicts the church in what is evidently its ideal or noumenal form as "not the object of a possible experience" but, instead, as "the church invisible" offering "the mere idea of the union of all upright human beings under direct yet moral divine world-governance" (RGV 6:101; emphasis Kant's). The motif of "invisibility," of course, refers to the inability of finite beings, possessing only a sensuous and not an intellectual intuition, to detect the moral status of any given moral agent. As Kant puts it earlier in Religion, "outer experience ... does not disclose the inwardness of the [moral] disposition but only allows inferences to it, though not with strict certainty" (RGV 6:63). The invisible church thereby serves as "the archetype of any such governance to be founded by human beings" (RGV 6:101). ${ }^{11}$ By definition, then, the invisible church cannot be recognized empirically, although reason holds out the possibility of this "hidden" community of virtuous agents both in and outside the "visible" church. By contrast, the "church visible is the actual union of human beings into a whole that accords with this ideal" (RGV 6:101).

\section{Emerging Ambiguities}

There is of course a range of ways in which we could understand the relationship of the visible to the invisible church. The interpretive options and nuances would be further complicated in Kant's own day by the varied denominational and sectarian interests in the notion of the invisible church. ${ }^{12}$ Yet these interpretive difficulties surely do not change the fact that Kant's overall reasoning process appears to be a clear endorsement of the religious setting for the flourishing of the ideal ethical community. At the same time - and even apart from Kuehn's concern about God's connection to Kant's ethical community - certain interpretive oddities appear. For example, in Part Three of Religion, Kant understandably depicts the visible church as the institutional expression of "ecclesiastical faith." Ecclesiastical faith is related to the idea of a "historical faith" that is dependent for its meaning and truth on an appeal to revelatory events in the past. The distinction would be a familiar one in Kant's period, with its extended debates over the relationship between natural and revealed religion. Kant speaks of "a historical faith which we can call 'ecclesiastical' in contradistinction to 'pure religious faith" (RGV 6:105).

Now of course a central aim of Religion is to clarify the relationship between revealed religion and pure religious faith, with Kant's commitment to a pure rational faith

\footnotetext{
${ }^{11}$ Notice here the parallel between Kant's depiction of the invisible church as the "archetype" of authentic moral governance and his depiction earlier in Religion (RGV 6:60-61) of the Son of God as the "prototype of the moral disposition in its entire purity." Kant's original German term in the cases of both "archetype" and "prototype" is Urbild.

${ }_{12}$ Pasternack (2014): 180 notes Kant's departure here from post-Reformation rhetorical uses of the distinction between the visible and the invisible church. Sullivan (1989): 216n. suggests that Kant's understanding of the invisible church has its Christian roots in St. Paul's concept of the corpus mysticum.
} 
having a reductionistic impact on appeals to events in the past. ${ }^{13}$ His general position on the issue is succinctly captured in one of Kant's comments about biblical exegesis when he states that we

should not quarrel over an issue unnecessarily, and over its historical standing, when, however we understand it, the issue does not contribute anything to our becoming a better human being ... Historical cognition has no intrinsic relation, valid for everyone, to [moral improvement] (RGV 6:43).

The visible church thus becomes a crucial element in Kant's effort to clarify the relationship between ecclesiastical and rational religious aims.

Yet Kant's most explicit way of depicting this relationship is very problematic with respect to the status of the visible church over the longer term in the future. At several points in Part Three of Religion, Kant refers to ecclesiastical faith as the "vehicle" for the aims of moral religion (RGV 6:106; 6:115; 6:118; 6:123n.). In one sense, the visible church, as the institutional form of this "vehicle," would seem to be crucial, since Kant argues that it is due to "the unavoidable limitation of human reason" that "historical faith attaches itself to pure religion as its vehicle" (RGV 6:115). Indeed, he speaks of "the natural need of all human beings to demand for even the highest concepts and grounds of reason something that the senses can hold on to" for which "some historical ecclesiastical faith or other, usually already at hand, must be used" (RGV 6:109; emphasis Kant's). Church, scripture, and the symbolic manifestations associated with public worship would thus mediate between the noumenal world of moral truth and the earth-bound sensuous world of rational yet finite agents who have a "natural need" for something their "senses can hold on to." One might therefore infer that the visible church (and all its trappings) continues through history as the needed locus of what Kant refers to as a "continual approximation to the ultimate perfection" that would involve the "gradual transition from ecclesiastical faith to the universal religion of reason" (RGV 6:122).

But what do we actually reach over time, and, in particular, how are we to take Kant's reference to "continual approximation?" There is of course a long history of scholarly debate about this very point since, in the full context of Kant's ethical thought, he is effectively raising the question of how fully the highest good can actually become realized in history. ${ }^{14}$ "Continual approximation" carries asymptotic connotations, suggestive of a destination approached but never actually reached. Indeed, Kant notes at one point that the "idea of an ethical community" is "never fully attainable" (RGV 6:100).

Adding to the interpretive uncertainty here is the fact that Kant refers to the "true church" as having "consciousness of its own contingency" and "carries a principle for

\footnotetext{
${ }^{13}$ Initial confusion about this aim when Religion was first published is evident in Kant's effort to clarify his emphasis on the relationship between "revealed" or historical faith and the "pure religion of reason" in his Preface to the second edition (RGV 6:12-13).

${ }^{14}$ A representative lightening rod in these interpretive debates is the aggressive stance of Yovel, who argues that, from the third Critique on, the "highest good becomes the 'final end of creation' itself, i.e., the consummate state of this world. Its realization is conceived as the 'kingdom of God on earth;' and despite its infinite remoteness, it involves a concrete synthesis to be realized in time, between the moral will and empirical reality." Yovel (1980): 72, emphasis Yovel's.
} 
continually coming closer to pure religious faith until finally we can dispense of that vehicle" (RGV 6:115; emphasis added). ${ }^{15}$ We might say that Kant apparently endorses the authenticity of any given ecclesiastical faith to the extent that it recognizes that its own historical claims are transparent to deeper moral truths that are independent of the truth or falsity of the historical claims in question. Viewed from this angle, Kant's position apparently implies that the true church is the one that is willing to put itself out of business over time. One encounters here echoes of Alasdair MacIntyre's playful characterization of liberal mediating Protestant theology - for which Kant is the preeminent philosophical influence - as "giving the atheist less and less in which to disbelieve."16

It thus becomes difficult to state straightforwardly Kant's position on the necessity of the visible church throughout history for the sake of moral ends. While he speaks of the "dispensability" of the church over time, he also suggests at one point that visible forms of ecclesiastical faith will be dissolved only when "all earthly life ... comes to an end" (RGV 6: 135n.; emphasis added). Rather tellingly - as if to capture intentionally his own apparent equivocation - Kant added the following footnote to the second edition of Religion:

Not that [historical faith] "will cease" (for it might always be useful and necessary, perhaps, as vehicle) but that "it can cease"; whereby is intended only the intrinsic firmness of pure moral faith (RGV 6:135n.; emphasis added).

In his own philosophical terms, Kant seems to be raising the question of whether a possibility in principle will at some point become a possibility in fact. The suggestion here of a kind of "thought experiment" hardly offers the strong basis on which to rest a definitive point of view. As a result, there is simply no transparent and uncontroversial route to an interpretive resolution of Kant's view of the visible church as the necessary locus of moral improvement over time. One might even say that his own effort to clarify his position serves mainly to underscore its ambiguity rather than eliminate it.

\section{The Kingdom of Ends and the Visible Church}

Questions about the long-term need for the visible church as the irreplaceable locus of the ethical community imply that the church may primarily be a placeholder in the drive toward a more secular destination. The initial predominance of the religious over the political dimensions in Kant's account of the ethical community masks the possibility that the explicitly religious feature may fade in time. Such a result would follow the pattern that Kant has already established with his view of historical events associated with ecclesiastical faith. From the ethical standpoint, we make progress only when we embrace historical events for their deeper moral meaning rather than for their literal

15 On the distinction between Kant's visible church and the "true" church, see Rossi (1998): 66-68. For a helpful account of how we can think of Kant's view of the relationship between the universal religion of reason and particular ecclesiastical faiths, see Tomaszewska (2016): 139-141.

${ }^{16}$ MacIntyre, Ricoeur (1969): 24. 
accuracy. Viewed within this wider context, the status of the visible church is, at the very least, highly debatable.

Moreover, Kuehn's suggestion of the strained nature of Kant's continuing references to God in his account of the ethical community naturally creates additional pressures on the community's religious dimensions. Kuehn's specific concern involves Kant's claim that the ethical community "must be a community under God," a point that emerges, as we have seen, in Kant's depiction of a "duty sui generis." An "ethical community," Kant tells us, "is conceivable only as a people under divine commands" (RGV 6: 99). Why must this be so?

Some interpretive guidance is suggested by recognizing that Kant's turn to community, ultimately leading to the visible church, actually finds its staring point in his account of the "kingdom of ends" eight years earlier in the Groundwork. ${ }^{17}$ In that previous context, Kant introduced the third formula of the categorical imperative with the claim that a "rational being must always consider itself as legislating in a kingdom of ends possible through freedom of the will," adding that morality "thus consists in referring all action to the legislation by which alone a kingdom of ends is possible."

This legislation must, however, be found in every rational being itself, and be able to arise from its will, the principle of which is thus: to do no action on a maxim other than in such a way that the will could through its maxim consider itself as at the same time universally legislating (GMS 4:434; emphasis Kant's).

In his statement of the obligations of members of the kingdom of ends, Kant carries through in community terms the mandate of universalizability in his initial and more familiar formula of the categorical imperative: "act only according to that maxim through which you can at the same time will that it become a universal law" (GMS 4:434; emphasis Kant's). A principle that at first appears to have application simply to the case of the individual moral agent turns out to have an important - indeed, vital - bearing on the agent as a member of the entire community of moral actors.

In important respects, then, the third formula of the categorical imperative anticipates Kant's account of a duty sui generis in Religion. With respect to Kant's ultimate distinction in Religion between the invisible and the visible church, it is significant that the Groundwork explicitly refers to the kingdom of ends as "only an ideal" (GMS 4:433; emphasis added). The "kingdom of ends has practical though non-sensible reality in the will of each rational being in whom this ideal arises from their moral agency." 18 By contrast, his reflections on the ethical community in Religion convey Kant's growing interest in the actual historical development of such a community, or what Despland has labeled "an intra-historical possibility" and not merely an "other-worldly one."19 One might say that Kant is seeking to provide empirical embodiment for what he had previously depicted in purely formal or ideal terms. This point dovetails in telling ways with the fact that the locus of moral progress in Religion has shifted to the future his-

\footnotetext{
17 Anderson-Gold (2001): 47-50.

18 Flikschuh (2009): 136.

19 Despland (1973): 207.
} 
tory of the ethical community, leaving behind all consideration of the postulate of the immortality of the soul that had played that role in the second Critique. In combination, Kant's shift beyond reflection on the ideal community as only "an ideal" together with his shift from the immortality of the (individual) soul to the ethical community as the locus of moral progress convey the important transitions occurring in his thought. ${ }^{20}$

The direction of Kant's thinking from the Groundwork to Religion would initially appear to reinforce the suggestion of a growing emphasis on a religious rather than a political setting for the realization of the ideal set by the third formula of the categorical imperative. "Structurally," Katrin Flikschuh argues, "the third formulation of the categorical imperative anticipates, not Kant's political philosophy, but the second Critique's doctrine of the postulate of God's existence and the related ideal of the Highest Good." Flikschuh refers as well to Höffe's suggestion that "the better parallel between a reading of the kingdom of ends and the ideal of an ethical order may lie in Kant's discussion of a possible 'ethical commonwealth' as an 'invisible church' in Religion." 21

Such a perspective would obviously support the view that Kant's account of the visible church is the natural next step in the direction of an actual empirical embodiment of the ethical community. Certainly at one level Flikschuh's point is compelling, due to the way the religious themes she mentions do indeed become visible in Kant's works following the Groundwork. But if we turn this point around, we realize anew that the religious element was originally marginalized or absent altogether in the Groundwork itself. In particular, God receives only the barest mention in that work and is mentioned merely by implication in Kant's actual discussion of the kingdom of ends (GMS 4:433434). In other words, the original formula for the conception of a community that is truly "ethical" by Kant's terms needed no theological scaffolding. With this point in mind, we might indeed find Kant's subsequent effort in Religion to include God in the account of the ethical community a bit "strained," or at least after the fact.

Moreover, the postulation of God's existence in the second Critique alluded to by Flikschuh is necessitated by the preceding postulation of the immortality of the soul. Yet as we have seen, this issue entirely disappears in Religion, with the locus of moral improvement now rendered in the form of the ethical community in the battle against radical evil. On the face of it, the shift from an individualistic emphasis on the immortality of the soul to a community-based conception of moral progress in history would surely suggest a secularizing rather than a religious shift. To be sure, the turn to the ethical community in Religion involves the flowering of seeds sown in the Groundwork, but it primarily conveys Kant's effort to define a zone of autonomy where moral agents could thrive in a genuinely ethical way rather than a robust interest in religious institutions for their own sake. The fact that the church was the only institutional setting recognizable

${ }^{20}$ DiCenso (2012): 133 provides a helpful summary of the larger issue here when he states that Kant is arguing "that the pursuit of ethical improvement requires that we apply autonomous laws of practical reason not just internally on our maxims, but also to modify external or statutory mores and laws." See also Guyer (2000): 372-407.

${ }^{21}$ Flikschuh (2009): 136. See her development of this train of thought with more explicit treatment of the church in Religion in Flikschuh (2011). 
in his day to which Kant could turn to avoid heteronomy is not the same thing as saying the visible church will always be the needed form of the ethical community.

Noteworthy, then, in the transition from the Groundwork to Religion is not simply Kant's effort to move from an "ideal" to a genuinely historical form for the ethical community, but also his more explicit references to God as its chief legislator. Recall that it is precisely the question of God's relationship to the ethical community that punctuates Kuehn's suggestion of strains in Kant's discussion of the ethical community. Obviously, then, the appropriate way to clarify the element of strain and its bearing on the issue of the visible church is to consider more directly God's relationship to the ethical community.

\section{God and the Ethical Community}

As we have seen, God is depicted in Religion as the "supreme lawgiver" of the ethical community who "knows the heart" of each of its members. What Kant then labels the "concept of God as a moral ruler" results in his claim that "an ethical community is conceivable only as a people under divine commands" (RGV 6:99).

Immediately following this claim, Kant disavows the notion that he is endorsing a theocracy (RGV 6:99-100). His apparent eagerness to make this point and avoid misunderstanding of his reference to "divine commands" is telling. The divine commands defining God's relationship to the ethical community are not arbitrary or otherwise quixotic instructions with no rational quality, for then we would be back in the heteronomous world of statutory laws that the genuinely ethical community is designed to avoid. In Kant's ethical community, by contrast, divine commands are the same as moral "duties," meaning that they are not duties because God commanded them. Instead, rational agents view them as divine commands since they recognize them to be duties. This commonplace point associated with Kant's own definition of religion ${ }^{22}$ suggests the same transparency between God and finite moral agents as exists for all finite moral agents in relation to one another within the idealized kingdom of ends. Kant implicitly makes the point himself in his discussion of theocracy, when he comments on the contrasting idea of a "lawgiver" who is "external" to the community, "whereas we only have to do here with an institution, of which the lawgiving is purely internal, a republic under laws of virtue, i.e., with a people of God 'zealous of good works"” (RGV 6:100; emphasis added). A "morality of tyranny and servility can be avoided" only if God and humanity together "form a moral community whose members are mutually comprehensible because they accept the same principles." 23

We thus see that Kant's effort to bring God into the account of the ethical community while simultaneously disavowing the idea of a traditional theocracy brings us back to the very same considerations that keep God from coming into clear view in the Groundwork. The transparency to one another of all members of the kingdom of ends arises from their mutual capacity to agree on what would count as "good reasons" in the ethical life. This capacity insures that the legislating authority within the kingdom of

\footnotetext{
22 "Religion is (subjectively considered) the recognition of all our duties as divine commands" (RGV 6:154-155); emphasis Kant's.

${ }^{23}$ Schneewind (1998): 510. See Korsgaard (1996): 62-65.
} 
ends will be shared among all its members. In Reath's characterization, an "agent with autonomy is not bound to any external authority and has the power to give law through the exercise of her will."

But such an agent must also be regarded as giving law to a community of agents, each of whom is as sovereign as she ... If the legislator's willing of a principle is to create reasons, it must carry immediate authority in itself, without depending on anything outside the legislator's will to give the 'subjects' reasons to acknowledge its normative force. ${ }^{24}$

If we consider in these terms the issue of the "sovereignty" over the ethical community in Religion, we begin to see motifs of partnership rather than of traditional theological "verticality" in the community's establishment. Sovereignty is implicitly shared, and God's role turns out to be something closer to cooperation than to oversight.

The central point at issue here is helpfully captured by Schneewind when he states that, for Kant, "God and we must be able to have a common understanding of the rationale or point of [moral] principles as well as of the actions they require." ${ }^{25}$ In this sense, at least, God is as much a member of the ethical community as its lawgiver, because the law that God is giving the community is something already known by its rational but finite members. "To be good is ... to be willed by a will governed by the moral law. Our will is such a will, and so is God's," Schneewind reminds us. Kant's "astonishing claim is that God and we can share membership in a single moral community only if we all equally legislate the law we are to obey." ${ }^{26}$ In short, the distinctiveness of God's supposedly special role in founding a "people of God" is gradually compromised as we reflect on God's relationship to the moral law and to the community's finite but rational members. In Banham's provocative summary of the issue, the idea of a moral community coming into existence through "the legislation of God" is simply the "statement that the legislation of such a community would be the autonomy of reason itself." 27

Emerging here is the possibility that there is something vaguely gratuitous about the references to God in the founding of the ethical community, a point that might be

\footnotetext{
${ }^{24}$ Reath (2006): 186, 187, emphasis Reath's.

${ }^{25}$ Schneewind (1998): 510. Schneewind represents Kant's career as the culminating moment in the seventeenth- and eighteenth-century debate over theological voluntarism. Relevant as well is the comment by Sullivan (1994): 88: “Thinking of God as moral ruler of this community... does not mean believing that ethical laws actually historically originated as commands of God, for taking God's will to be the basis of duty would reduce obedience to those laws to nonmoral heteronomy. Every member must share in the headship of this church, for if we were only subjects, with duties but no rights, we would be denied our dignity as persons."

${ }^{26}$ Schneewind (1998): 512, emphasis added. Schneewind adds: "The mature Kant does not hesitate to make an explicit comparison between human agents and God." See the effort to sort out God's relationship to Kant's ethical community in Michalson (2001).

${ }^{27}$ Banham (2003): 150. Banham makes this point in connection with his interesting and - in the current context - very telling use of Kant's notion in Religion of the concept of a "schematism of analogy" (RGV 6:65n.), stating that "for a moral community to come into existence is for all peoples to submit to the legislation of God, but ... the term God is the product of a schematism of analogy, and what we rationally mean by it is the universal aim of perfect moral accord" (emphasis added).
} 
at the heart of Kuehn's uneasiness with Kant's account. If we extend our perspective on this point to include the Opus postumum, we might conclude with Guyer that Kant "devoted much of his effort to describing the idea of God as an idea that we create for ourselves in order to express the authority over all our natural inclinations and desires that we ourselves give to the categorical imperative." Guyer adds Kant's own remark from the Opus postumum itself:

The categorical imperative represents all human duties as divine commands: not historically, as if [God] had ever issued certain orders to man, but as reason [presents] them through the supreme power of the categorical imperative, in the same manner as a divine person can rigorously command submission to himself. ${ }^{28}$

By this reading, a plausible and important implication emerges: to the extent that God shares with all rational beings the obligation to the moral law, the idea of God as a being external to reason itself gradually thins out. Kant himself suggests as much in the Preface to the first edition of Religion: "Agreement with the mere idea of a moral lawgiver for all human beings is indeed identical with the moral concept of duty in general, and to this extent the proposition commanding the agreement would be analytic" (RGV 6:6n.).

We thus gradually see how the issue of sovereignty over the ethical community flows into the vexed issue of Kant's view of God or, more directly expressed, Kant's view of God's relation to rationality itself. The central question is whether Kant's account of a seemingly "shared" sovereignty so compromises God's role as to result in a diminishing of God's metaphysical status. Together with the related issue of Kant's relationship to Christianity, this issue has been a subject of lively debate in the context of the fresh waves of interpretive interest in Kant's Religion in recent decades. ${ }^{29}$

With their accounts resulting in a thinning out of robust God-talk in Kant, commentators such as Banham and Guyer occupy one end of the spectrum of such debates. Naturally, critics of such a position could reasonably respond by arguing that full commensurability between God and rationality does not in itself undermine the metaphysical status of God, and that to argue that it does is simply to assume that "all religion, and Christianity in particular, must be of the kind with a voluntaristic God at the helm."

Why should a belief in the rationality of God lead to God becoming an unnecessary hypothesis? Cannot God be conceived as a kind of universal mind that is the condition of the possibility of the harmonization of the intelligences, especially given that there may be elements of harmonization that move beyond what each rational will can achieve on its own? ${ }^{30}$

\footnotetext{
${ }^{28}$ Guyer (2000): 402-403. See also the effort by Eckart Förster (2000): 137 to shed light on the ethical community "under God" in light of the Opus postumum. The concept of God "is connected analytically with the concept of duty, or better, with the categorical imperative insofar as the latter is thought as 'the principle of unification' (Vereinigungsprinzip) of free moral beings."

${ }^{29}$ For a useful overview of these issues, see Chignell, Anderson, Firestone et al. (2012).

${ }^{30}$ Comments offered by an anonymous reader of an earlier version of this paper. Consider also Mariña's recent remark (2017): 303n., made in response to DiCenso's (2011) account of Kant's view of grace, that DiCenso's suggestion that for Kant God "is a useful fiction is certainly mistaken."
} 
My own present purposes hardly require a definitive resolution of the question of Kant's God for the simple reason that my aim is to draw to the surface the ambiguity of his account of the visible church. This ambiguity is only heightened by the fact of serious debates about the referential status of language about God in Kant's thought. Bear in mind that it is the need for a "supreme lawgiver" that initially leads Kant to speak of the ethical community as a "people of God" ultimately involving the visible church. Once again, it is specifically this move on Kant's part that Kuehn characterizes as "strained." Debates about the status of God-talk in Kant do not make the strain - or the ambiguity go away. They only underscore the issue.

\section{Secularization and Kant's Ethical Community}

As we have seen, the driving force in Kant's turn toward a religious context as the locus of moral improvement is his search for a safe space for autonomy. Certainly this feature of his main writing on religion creates the appearance that, late in his career, Kant is enhancing the future importance of religious institutions. Yet the explicitly "religious" dimension of his position, framed in terms of the role played by the visible church, depends heavily on an account of sovereignty that, upon inspection, appears to be shared rather than lodged solely in God - a horizontal rather than vertical relationship between God and finite moral agents that makes increasingly problematic the idea of a divine being "external" to the internally available moral law. The actual details of Kant's position thus convey a compromised sense of the theistic element that was central to the Christian understanding of religion in Kant's day. This point results from the very same issue directing Kant toward a religious rather than political locus in the first place, namely, his quest for an institutional setting where autonomy can thrive. In Rossi's apt characterization, the ethical community is an "ostensibly theological model" but its "full import bears upon the widest range of human conduct." 31

Rossi's remark invites reflection on the kind of institutional setting for the ethical community that could, over time, assume secular form without necessarily becoming political in nature. Certainly this is not to say that the secular version of the ethical community is easy to imagine or depict but only that - by his own terms - Kant is offering a potentially misleading dichotomy in Religion between either a political setting (and therefore heteronomous) or a religious one (and thus a safe haven for autonomy). Musing on such issues, Onora O'Neill suggests that the "context of action" for Kant's ethical community "may but need not be framed by the life of a church," adding that Kant's account "allows at least a transitional role to ecclesiastical faith and the visible church, but it is not clear whether it allows more."

Can the empirical realities and institutional structures of a church (or of another social but secular 'vehicle') be wholly superseded? If so, what is to bind the members of the ethical commonwealth together? If there are shared duties 'of the human race',

\footnotetext{
${ }_{31}$ Rossi (1998): 68. With a view to the strictly "theological model," Tampio (2014) offers a Rawlsian account of the neglected issue of the prospects for religious pluralism in Kant's ethical community, including extended consideration of Islam.
} 
will their enactment not require shared public practices and institutions? If so, will not our hopes, including our shared hopes, have to be connected to shared activities and institutional structures, whether religious or this-worldly? ${ }^{32}$

In light of Kuehn's uneasiness over God's relationship to the ethical community, the deeper point here may have less to do with the ideal ethical community and more to do with transitions in the very idea of "transcendence" occurring in this moment in Kant's work. We have seen that, subtly emerging in Kant's depiction of the ethical community, is something more like divine transcendence commingling with the capacity for "self-transcendence" among finite rational beings through their ability to recognize and obey the moral law. God does not miraculously enter the phenomenal world to transmit the moral law. Rather, the finite agent elevates itself beyond its otherwise lowly condition "as a mere speck in the universe" through recognition of the moral law that "presents me in a world which has true infinity... and infinitely raises my worth" (KpV 5:162). Discovering divine commands just is the recognition of my duties in this self-transcending way. Kant's ethical community serves as the setting for this self-transcendence at the collective level, which constitutes its potential role in overcoming radical evil. It is this collective or community aspect that will ultimately offset the fact that "the forces of single individuals" are "insufficient on their own" (RGV 6:98). All along, the goal is not to acknowledge and honor "God's will" but to perceive that God's will is simply another way of talking about our sense of moral obligation delivered to us as a "fact of reason" (KpV 5:31) and not as a message from above. Viewing "religion" as the "recognition of all our duties as divine commands" is thus not a means of citing God as the source of moral duties but a means of emphasizing how seriously we take our duties - with God and humanity similarly obligated. ${ }^{33}$ The issue at stake is not the origin of the moral law but the degree of our diligence in relation to it.

For these and other reasons, Kant's push toward the ethical community might fruitfully be viewed as a moment in secularization rather than as a robustly religious standpoint necessitating the visible church in perpetuity. He was simply living too early for his full range of institutional options to become clear, ${ }^{34}$ and, since it was obvious that

32 O'Neill (2015): 246-247, emphasis O'Neill's. See also DiCenso (2012): 174-177.

${ }^{33}$ Sullivan (1994): 88.

${ }^{34}$ Kant was of course also saddled with the lingering effects of a Christian tradition involving a doctrine of original sin that is clearly replicated in Kant's terms in his doctrine of radical evil. This similarity, after all, is why Kant himself opens up the question of divine grace in consideration of the question of how best to overcome radical evil. It is important to note that, in his allusions to divine aid under the conceptually flexible ground rules of the four "General Observations" in Religion, Kant does not describe how God rescues us from radical evil but only what moral regeneration looks like from the divine perspective. To God, moral regeneration looks like a "revolution" in the underlying moral disposition, and not like an "evolution" (RGV 6:47-48), a distinction introduced because God possesses a noumenal rather than a sensible intuition. With respect to the specific question of how and whether God offsets our moral debility in the recovery from radical evil - which is of course the question of grace - Kant's account is utterly uninformative, which it has to be if autonomy is to be protected. This issue would not change if we shifted our perspective to how God somehow offsets the collective failings of the ethical community. In both cases, divine aid is simply an object of "hope," though it is a rational hope. For a comprehensive overview of interpretive options regarding Kant's concept of grace, see Muchnik and Pasternack (2017). See also Mariña (1997). 
he could not satisfy the demands of autonomy through political means, he had no place else to go. One is reminded here of Protestant theologian Dietrich Bonhoeffer's ruminations from a Nazi prison about "religionless Christianity." Christianity "has always been a form - perhaps the true form - of 'religion,'" Bonhoeffer suggests, but what if one day we discover that this "religious form" was a "historically conditioned and transient form of human self-expression," and that "religion is only a garment of Christianity" and not the real thing? What if "religion" turns out to be analogous to what circumcision was for St. Paul - clearly critical in its day but utterly dispensable as time passes and conditions change? "The Pauline question whether circumcision is a condition of justification seems to me in present-day terms to be whether religion is a condition of salvation," Bonhoeffer writes. By this reasoning, freedom "from circumcision is also freedom from religion." 35

Kant's comments on ecclesiastical faith as the "vehicle" for pure moral faith bear a strong family resemblance to Bonhoeffer's musings about religionless Christianity. In what he provocatively calls a "representation in a historical narrative of the future world, which is not itself history," Kant offers a section of Religion titled, "Historical Representation of the Gradual Establishment of the Dominion of the Good Principle on Earth." Here he provides a comparative account of the history of ecclesiastical faith that depicts what the "church universal" might look like one day. In contrast to an historical faith that "bases itself on books," the "pure faith of reason ... does not need any such documentation but is its own proof" (RGV 6:129). It is self-validating.

Kant concludes this section by suggesting that "we have a glimpse" (hinaussehen) of "the continuous advance and approximation toward the highest possible good on earth..." (RGV 6:136; emphasis Kant's). Yet by now in Religion we can clearly appreciate that this is an advance by subtraction, with moral progress defined by what we can leave behind in the approximation toward a goal that carries its own proof - not unlike Bonhoeffer's musings about leaving behind "religion" as a historically contingent and ultimately dispensable appendage to the thing itself. Needed by Kant in his day as a safe haven for autonomy, the visible church may in time be one more thing that is left behind. When it comes to trappings and embellishments in Kant's projected moral community, less is better. ${ }^{36}$

\section{References}

Anderson-Gold S. (2001), Unnecessary Evil: History and Moral Progress in the Philosophy of Immanuel Kant, State University Press of New York, Albany.

Anderson-Gold S., Muchnik P. (eds.) (2010), Kant's Anatomy of Evil, Cambridge University Press, Cambridge.

Banham G. (2003), Kant's Practical Philosophy: From Critique to Doctrine, Palgrave Macmillan, London.

Bonhoeffer D. (1972), Letters and Papers from Prison, E. Bethge (ed.), Macmillan, New York.

\footnotetext{
${ }_{35}$ Bonhoeffer (1972): 280, 281.

${ }^{36}$ My thanks to two anonymous reviewers of an earlier version of this article for their thoughtful feedback.
} 
Chignell A., Anderson P., Firestone C. et al. (2012), “Symposium: Kant's Philosophy of Religion," Faith and Philosophy 29: 144-228.

Despland M. (1973), Kant on History and Religion, McGill-Queen's University Press, Montreal, London.

DiCenso J.J. (2012), Kant's Religion within the Boundaries of Mere Reason: A Commentary, Cambridge University Press, Cambridge.

DiCenso J.J. (2019), “Kant on Ethical Institutions," The Southern Journal of Philosophy 57 (1): 30-55.

Flikschuh K. (2009), “Kant's Kingdom of Ends: Metaphysical, not Political,” [in:] Kant's Groundwork of the Metaphysics of Morals: A Critical Guide, J. Timmermann (ed.), Cambridge University Press, Cambridge: 119-139.

Flikschuh K. (2011), “Gottesdienst und Afterdienst: die Kirche als öffentliche Institution?,” [in:] I. Kant, Die Religion innerhalb der Grenzen der bloßen Vernunft, O. Höffe (ed.), Akademie Verlag, Berlin: 193-210.

Förster E. (2000), Kant's Final Synthesis: An Essay on the Opus Postumum, Harvard University Press, Cambridge MA.

Grenberg J.M. (2010), “Social Dimensions of Kant's Conception of Radical Evil,” [in:] Kant's Anatomy of Evil, S. Anderson-Gold, P. Muchnik (eds.), Cambridge University Press, Cambridge: 173-194.

Guyer P. (2000), Kant on Freedom, Law, and Happiness, Cambridge University Press, Cambridge.

Guyer P. (2009), “The Crooked Timber of Mankind," [in:] Kant's Idea for a Universal History with a Cosmopolitan Aim: A Critical Guide, A. Rorty, J. Schmidt (eds.), Cambridge University Press, Cambridge: 129-149.

Höffe O. (ed.) (2011), Die Religion innerhalb der Grenzen der bloßen Vernunft, Akademie Verlag, Berlin.

Kant I. (1793/1996), Religion within the Boundaries of Mere Reason, trans. G. Di Giovanni, [in:] I. Kant, Religion and Rational Theology, A.W. Wood, G. Di Giovanni (eds.), Cambridge University Press, Cambridge: 39-216.

Kant I. (1788/1997), Critique of Practical Reason, trans. M.J. Gregor, [in:] I. Kant, Practical Philosophy, M.J. Gregor (ed.), Cambridge University Press, Cambridge: 133-272.

Kant I. (1785/2012), Groundwork of the Metaphysics of Morals, trans. and ed. M.J. Gregor, J. Timmermann, Cambridge University Press, Cambridge.

Kneller J., Axinn S. (eds.) (1998), Autonomy and Community: Readings in Contemporary Kantian Social Philosophy, State University of New York Press, Albany.

Korsgaard C. (1996), Creating the Kingdom of Ends, Cambridge University Press, Cambridge.

Kuehn M. (2001), Kant: A Biography, Cambridge University Press, Cambridge.

Louden R. (2011), Kant's Human Being: Essays on His Theory of Human Nature, Oxford University Press, New York.

MacIntyre A., Ricoeur P. (1969), The Religious Significance of Atheism, Columbia University Press, New York, London.

Mariña J. (1997), “Kant on Grace: A Reply to his Critics," Religious Studies 33: 379-400.

Mariña J. (2017), “Kant's Robust Theory of Grace," Con-Textos Kantianos 6: 302-320.

Michalson G. (1999), Kant and the Problem of God, Blackwell, Oxford.

Michalson G. (2001), "God and Kant's Ethical Commonwealth," The Thomist 65: 67-92.

Michalson G. (ed.) (2014), Kant's Religion within the Boundaries of Mere Reason: A Critical Guide, Cambridge University Press, Cambridge. 
Miller E. (2015), Kant's Religion within the Boundaries of Mere Reason, Bloomsbury, London. Muchnik P., Pasternack L. (2017), "A Guide to Kant's Treatment of Grace," International Journal of Philosophy 6: 256-271.

O'Neill O. (2015), Constructing Authorities: Reason, Politics and Interpretation in Kant's Philosophy, Cambridge University Press, Cambridge.

Palmquist S.R. (2017), “Kant's Model for Building the True Church: Transcending 'Might Makes Right' and 'Should Makes Good' through the Idea of a Non-Coercive Theocracy," Diametros 54: 76-94.

Pasternack L. (2014), Kant on Religion within the Boundaries of Mere Reason: An Interpretation and Defense, Routledge, London, New York.

Reath A. (2006), Agency and Autonomy in Kant's Moral Theory: Selected Essays, Oxford University Press, Oxford.

Rorty A., Schmidt J. (eds.) (2009), Kant's Idea for a Universal History with a Cosmopolitan Aim: A Critical Guide, Cambridge University Press, Cambridge.

Rossi P.J. (1998), "Public Argument and Social Responsibility: The Moral Dimensions of Citizenship in Kant's Ethical Commonwealth," [in:] Autonomy and Community: Readings in Contemporary Kantian Social Philosophy, J. Kneller, S. Axinn (eds.), State University of New York, Albany: 63-85.

Schneewind J. (1998), The Invention of Autonomy, Cambridge University Press, Cambridge. Sullivan R.J. (1989), Immanuel Kant's Moral Theory, Cambridge University Press, Cambridge. Sullivan R.J. (1994), An Introduction to Kant's Ethics, Cambridge University Press, Cambridge. Tampio N. (2014), "Pluralism in the Ethical Community," [in:] Kant's Religion within the Boundaries of Mere Reason: A Critical Guide, G. Michalson (ed.), Cambridge University Press, Cambridge: 175-192.

Timmermann J. (ed.) (2009), Kant's Groundwork of the Metaphysics of Morals: A Critical Guide, Cambridge University Press, Cambridge.

Tomaszewska A. (2016), "Kant's Reconception of Religion and Contemporary Secularism," Roczniki Filozoficzne 64 (4): 125-148.

Wood A.W. (1999), Kant's Ethical Thought, Cambridge University Press, Cambridge.

Wood A.W. (2011), "Ethical Community, Church and Scripture," [in:] Die Religion innerhalb der Grenzen der bloßen Vernunft, O. Höffe (ed.), Akademie Verlag, Berlin: 131-150.

Yovel Y. (1980), Kant and the Philosophy of History, Princeton University Press, Princeton. 